\title{
The Urgency of Using Internet-Based Arabic Learning Media in Online Learning in the Global Pandemic Era
}

\author{
Mabruri $^{1}$, Hamzah $^{2}$ \\ ${ }^{1}$ STIT YAPIMA Muara Bungo, Jambi \\ 1 e-mail: mabrurilana@yahoo.co.id \\ ${ }^{2}$ Insitut Agama Islam DDI Polewali Mandar, Sulawesi Barat \\ 2 e-mail: hamzah87_aziz@ymail.com
}

\begin{abstract}
The minister of education and culture conveyed his instructions for carrying out online learning in the context of preventing the spread of Corona Virus Disease (COVID-19). Through this Online Learning, an educator can face to face with their students through an application that can be accessed by an internet network. Online learning cannot be separated from internet-based media, because online learning requires internet network access. Using internet-based media in the era of a global pandemic is something that is considered urgent or urgent in the midst of government policies to avoid crowds in anticipation of the spread of a global pandemic. Internet-based Arabic learning media has some urgency in online learning in the era of the global pandemic, one of the main reasons is as a connection medium for communicating, interacting and face-to-face over long distances with students amidst the spread of Covid-19.
\end{abstract}

Keywords: Arabic learning media, online learning, internet-based Arabic learning media

\begin{abstract}
Abstrak
Menteri pendidikan dan kebudayaan menyampaikan intruksinya untuk melaksanakan pembelajaran secara daring dalam rangka pencegahan penyebaran Corona Virus Disease (COVID-19). Melalui Pembelajaran Daring ini, seorang pendidik dapat melakukan tatap muka bersama peserta didiknya melalui aplikasi yang dapat diakses dengan jaringan internet. Pembelajaran daring tidak dapat dipisahkan dari media berbasis internet, karna pembelajaran daring membutuhkan akses jaringan internet. Menggunakan media berbasis internet di era pandemi global merupakan suatu hal yang dianggap mendesak ataupun urgensi ditengah-tengah kebijakan pemerintah untuk menghidari keramaian dalam rangka antisipasi penyebaran pandemi global. media pembelajaran bahasa arab berbasis internet memiliki beberapa urgensi dalam pembelajaran daring pada era pandemic global, salah satu alasan utama ialah Sebagai media koneksi untuk berkomunikasi, berinteraksi dan bertatap muka jarak-jauh dengan peserta didik ditengah maraknya penyebarab Covid-19.
\end{abstract}

Kata Kunci: Media pembelajaran, microsoft power point, pembelajaran kemahiran berbahasa Arab 


\section{Loghat Arabi: Jurnal Bahasa Arab \& Pendidikan Bahasa Arab}

\section{Introduction}

On March 22020 for the first time the Indonesian government announced two cases of positive Covid-19 patients, ${ }^{1}$ which most likely have entered Indonesia since early January. Since the announcement of this Covid-19 case by the government, Indonesia has officially become a country affected by the global pandemic originating from Wuhan Province, China. In the era of this global pandemic, Indonesia's economic activities have continued to decline. not only the economy but education and learning activities in Indonesia have also been affected by this global pandemic

As a result of this global pandemic, the minister of education and culture conveyed his instructions through letter No. 36962/MPK.A/HK/2020 which reads about online learning and working from home in order to prevent the spread of Corona Virus Disease (COVID-19). ${ }^{2}$ Sofyana and Abdul in their article stated that Online Learning is a learning system that is carried out not face to face, but using a platform that can help the teaching and learning process carried out even though it is a long distance. The purpose of online learning is to provide quality learning services in a network that is massive and open to reach learning space enthusiasts so that more and wider ${ }^{3}$. Of course, the operational capability must be possessed and mastered by an educator in any field of study, as well as especially for Arabic language teachers in schools or madrasah.

Online learning is nothing new and familiar in the world of education, but online learning is still little used by teachers, even if Arabic language lecturers before the onset of this global pandemic. So that in online learning there are not a few Arabic teachers and lecturers who are rigid in implementing it. Through this Online Learning, an educator can face to face with their students through an application that can be accessed by an internet network $^{4}$. The internet is one of the means or media to obtain information, easily and quickly,

${ }^{1}$ Ellyvon Pranita, Diumumumkan Awal Maret, Ahli: Virus Corana Masuk Indonesia dari Januari, dalam situs berita https://www.kompas.com/sains/read/2020/05/11/130600623/diumumumkan-awal-maret-ahli--viruscorana-masuk-indonesia-dari-januari diakses pada tanggal 11 Nopember 2020.

${ }^{2}$ Kementerian Pendidikan dan Kebudayaan, SE Mendikbud: Pembelajaran secara Daring dan Bekerja dari Rumah untuk Mencegah Penyebaran Covid-19, https://www.kemdikbud.go.id/main/blog/2020/03/semendikbud-pembelajaran-secara-daring-dan-bekerja-dari-rumah-untuk-mencegah-penyebaran-covid19 diakses pada tanggal 17 Nopember 2020.

${ }^{3}$ Sofyana dan Abdul, Pembelajaran Daring Kombinasi Berbasis Whatsapp Pada Kelas Karyawan Prodi Teknik Informatika Universitas PGRI Madiun, dalam Jurnal Nasional Pendidikan Teknik Informatika, Vol. 8, No. 1, 2019, h. 81-86.

${ }^{4}$ Oktafia Ika Handarini dan Siti Sri Wulandari, Pembelajaran Daring Sebagai Upaya Study From Home (SFH) Selama Pandemi Covid 19, dalam Jurnal Pendidikan Administrasi Perkantoran (JPAP) Vol. 8, No. 3, 2020, h. 497. 
which results in a lot of knowledge obtained, so that qualified human resources can be achieved $^{5}$. Online learning cannot be separated from internet-based media, because online learning requires internet network access.

Regarding this media, Hamzah in his book emphasizes that teachers must also have another expertise in the field of information technology, especially the Internet, because nowadays teachers are required to be able to use the Internet because they can dig up more information besides what is in books ${ }^{6}$. In line with the above opinion, of course, in this global pandemic, teachers must further strengthen their operational competence in online learning through the use of internet-based media. Using internet-based media in the era of a global pandemic is something that is considered urgent or urgent in the midst of government policies to avoid crowds in anticipation of the spread of a global pandemic.

The fact of the current condition in Indonesia is that the global pandemic has undermined the rights of students and teachers to carry out face-to-face teaching and learning activities in the classroom. So whether we like it or not and like it or not, it is a must for an educator to use internet-based media in Arabic online learning. In the case above, the authors highlight and specifically examine the urgency of using this media as the main choice in continuing and carrying out teaching and learning process activities in this global pandemic era.

\section{Arabic Language Learning Media}

Media in the teaching and learning process tends to be interpreted as graphic, photographic, or electronic tools to capture, process and reconstruct visual and verbal information ${ }^{7}$. Media in the world of education will always develop and increase in type along with the advancement of times and technology. academics are competing to develop and introduce new media as alternatives and solutions to help and facilitate learning.

Various kinds of definitions are offered by intellectuals to the world of academia, including Amka's statement which defines learning media as a physical and non-physical tool that is deliberately used as an intermediary between educators and students in understanding learning material to make it more effective and efficient ${ }^{8}$. In another opinion, learning media is defined as everything that can transmit messages, can stimulate thoughts, feelings, and the

\footnotetext{
${ }^{5}$ Rusman, Perkembangan Teknologi Informasi (Jakarta: Raja Grafindo Perseda, 2007), h. 278.

${ }^{6}$ Hamzah B. Uno, Model Pembelajaran: Menciptakan Proses Belajar Mengajar yang Kreatif dan Efektif (Jakarta: Bumi Aksara, 2010), h. 3.

${ }^{7}$ Azhar Arsyad, Media Pengajaran (Jakarta: Raja Grafindo Persada, 2000), h. 3.

${ }^{8}$ Amka, Media Pembelajaran Inklusi (Sidoarjo: Nizamia Learning Center, 2016), h. 16.
} 
will of students so that it can encourage the creation of a learning process in students ${ }^{9}$. In addition, learning media can be understood as anything that can convey or transmit messages from a source in a planned and effective manner, so as to create a conducive environment where the recipient can carry out learning activities effectively and efficiently ${ }^{10}$.

From the explanation above, it can be interpreted in simpler terms that Arabic learning media is a means and equipment used for Arabic teaching and learning activities, which function as a teacher's assistant to deliver learning material more simply and easily understood so that the purpose of learning Arabic is already formulated can be achieved according to the target.

Arabic Learning Media in this era of sophisticated technological advances must do a lot of creative innovation and develop media products that are more influential in increasing the effectiveness of learning. In general, there are several choices of Arabic learning media that teachers can use in the learning process, namely:

1. Arabiyah Visual Media

2. Arabiyah Audio Media

3. Arabiyah Audio Visual Media

4. Interactive Multimedia

5. Android Based Media

6. Computer Based Media

7. Internet-based Media

If you look at the conditions and situations in the current global pandemic era, the main alternative choice is internet-based media which is a necessity or urgency to be used in the teaching process. However, that does not mean that during this global pandemic all media other than the internet cannot be used, but can be used by combining internet-based media with other media. Besides that, to demonstrate and use media other than the internet, you also need to access the internet network first. This is the author's strong reason for placing internetbased media as the main alternative in Arabic language learning in the current global pandemic era.

${ }^{9}$ Taufik, Pembelajaran Bahasa Arab MI (Surabaya: UIN Sunan Ampel Press, 2016), h. 129.

${ }^{10}$ Heri Susanto dan Helmi Akmal, Media Pembelajaran Sejarah Era Teknologi Informasi (Konsep Dasar, Prinsip Aplikatif, dan Perancangannya) (Banjarmasin: Program Studi Pendidikan Sejarah Fakultas Keguruan dan Ilmu Pendidikan Universitas Lambung Mangkurat, 2019), h. 16. 


\section{Internet-Based Media}

Not many people know that the Internet actually stands for Interconnection Networking. The internet itself is defined in various terms, some define the internet as an electronic communication network that connects computer networks and computer facilities organized around the world by telephone or satellite ${ }^{11}$. Another definition emphasized by Williams that the internet is a collection of computer networks so that users can share information with a wider range of sources ${ }^{12}$.

Internet technology is a type of e-education media that can create online two-way interactions. This media is used to develop the teaching and learning process, because in addition to being interactive, this media is connected to the global network of the world, so that the range of access is unlimited ${ }^{13}$. In this case, the Internet can be concluded as a window to the world of science without boundaries. Various ideas and thoughts that can be accessed by Students who are looking for knowledge in the internet world.

The internet is not limited to space and time, every computer connected to it can contact many computers at any time, and from anywhere in the world to send news, get information or transfer data ${ }^{14}$. In practice, in the current global pandemic era, teachers do not need to worry about the disruption of the learning process, because through this network learning can continue as long as internet access runs smoothly.

The internet is an information technology-based learning media that is considered more communicative, transformative, accurate, simple, flexible, informative and global in nature compared to other media in learning Arabic for students ${ }^{15}$. From some of the strands above, it can be concluded that internet-based media is a means and equipment that requires an internet network for teaching and learning activities, and serves as a teacher's assistant to deliver learning material remotely according to the curriculum formulation to be achieved.

In the case of the current global pandemic, students can carry out teaching and learning activities online, in addition to getting knowledge transfer from educators, students can also

\footnotetext{
${ }^{11}$ Tim Penyusun Kamus Pusat Bahasa, Kamus Bahasa Indonesia (Jakarta: Pusat Bahasa Departemen Pendidikan Nasional, 2008), h. 560.

${ }^{12}$ Hamzah B. Uno dan Nina Lamatenggo, Teknologi Komunikasi dan Informasi Pembelajaran (Jakarta: Bumi Aksara, 2011), h. 104.

${ }_{13}$ Muhamad Zacky Aminy, Pemanfaatan Media Internet Sebagai Sumber Belajar Mahasiswa Program Studi Pendidikan Matematika di STKIP Bima Semester Ganjil Tahun Pelajaran 2013/2014, dalam Jurnal KIP, Vol. 4, No. 2, 2015, h. 929.

${ }^{14}$ Bambang Warsita, Teknologi Pembelajaran Landasan \& Aplikasinya (Jakarta: Rineka Cipta, 2008), h. 143.

${ }^{15}$ Muhandis Azzuhri, Metode dan Media Pembelajaran Bahasa Arab Berbasis Internet di Era Teknologi Informasi, dalam Insania: Jurnal Pemikiran Alternatif Kependidikan, Volume 14, No. 3, 2009, h. 11.
} 
learn independently in enriching their insights through digital library e-books and or forming discussion groups among students and learning with educational websites.

Internet-based Arabic learning media in online learning can be the right choice for today's global conditions. through this media there are several selected applications that teachers and students can use to interact in online learning, including the following:

Table 1: Application connected to the internet

\begin{tabular}{|l|l|l|l|}
\hline No & Applications & Symbol & \multicolumn{1}{|c|}{ Description } \\
\hline 1. & Zoom Meeting & & $\begin{array}{l}\text { An applications that helps teachers and students } \\
\text { communicate remotely by combining video conferencing, } \\
\text { online meetings, chat and mobile collaboration. }\end{array}$ \\
\hline 2. & YouTube & $\begin{array}{l}\text { applications that contain creative video content, teachers } \\
\text { can upload learning videos or a variety of information } \\
\text { that is very helpful for students, even teachers can make } \\
\text { live Arabic learning. }\end{array}$ \\
\hline 3. & $\begin{array}{l}\text { Google } \\
\text { Classroom }\end{array}$ & $\begin{array}{l}\text { The learning management system application is used to } \\
\text { mediate the interaction between teachers and students to } \\
\text { provide teaching materials, to integrated tests for } \\
\text { assessments. }\end{array}$ \\
\hline 5. & Whats App & $\begin{array}{l}\text { Chat application that allows teachers to send students } \\
\text { learning content via messages, photos, videos and audio } \\
\text { and students can send assignments in the form of an } \\
\text { encrypted file. }\end{array}$ \\
\hline & $\begin{array}{l}\text { An application that allows teachers to deliver learning in } \\
\text { the form of online messages, photos, videos, audios and } \\
\text { sending learning files that students can learn } \\
\text { independently at home. }\end{array}$ \\
\hline
\end{tabular}

The Indonesian government through the Ministry of Education and Culture (Kemendikbud) has also taken a role in addressing the inequality of learning activities during this global pandemic. as reported on the official website of the Ministry of Education and Culture, there are 8 lists of pages that can be accessed and recommended as learning tools ${ }^{16}$ :

${ }^{16}$ Kementerian Pendidikan dan Kebudayaan, SE Mendikbud: Pembelajaran secara Daring dan Bekerja dari Rumah untuk Mencegah Penyebaran Covid-19, https://www.kemdikbud.go.id/main/blog/2020/03/semendikbud-pembelajaran-secara-daring-dan-bekerja-dari-rumah-untuk-mencegah-penyebaran-covid19 diakses pada tanggal 17 Nopember 2020. 
Table 2: List of pages recommended by the Ministry of Education and Culture

\begin{tabular}{|c|l|l|}
\hline No. & \multicolumn{1}{|c|}{ Name } & \multicolumn{1}{c|}{ Link Access } \\
\hline 1. & Rumah belajar & $\underline{\text { https://belajar.kemendikbud.go.id }}$ \\
\hline 2. & $\begin{array}{l}\text { Google G Suites } \\
\text { for Education }\end{array}$ & $\begin{array}{l}\text { https://blog.google/outreach-intiatives/education/offline- } \\
\text { access-covid19/ }\end{array}$ \\
\hline 3. & Kelas pintar & $\underline{\text { https://kelaspintar.id }}$ \\
\hline 4. & $\begin{array}{l}\text { Microsoft office } \\
365\end{array}$ & $\underline{\text { https://microsoft.com/id-id/education/products/office }}$ \\
\hline 5. & Quipper school & $\underline{\text { https://quipper.com/id/school/teachers }}$ \\
\hline 6. & $\begin{array}{l}\text { Sekolah Online } \\
\text { Ruang guru }\end{array}$ & $\underline{\text { https://ruangguru.onelink.me/blPk/efe72b2e }}$ \\
\hline 7. & Sekolahmu & $\underline{\text { https://www.sekolah.mu/tanpabatas }}$ \\
\hline 8. & Zenius & $\underline{\text { https://zenius.net/belajar-mandiri }}$ \\
\hline
\end{tabular}

The Indonesian government through the ministry of education and culture has worked hard in thinking of solutions for the sustainable education of the nation's children. Where before, students only had a lot of vacation and study independently without meeting face to face with the educators. Therefore, the role of formal education is taken over by parents or parents. The list of recommended pages by the Ministry of Education and Culture is one proof that the government is solutive and tries and thinks hard in selecting and recommending the latest learning tools in the era of the global pandemic.

\section{The Urgency of Using Internet-Based Media in online learning}

Broadly speaking, the urgency of the media in the learning process has the following functions:

1. Clarify the presentation of the message so that it is not too verbal so that it makes it easier for students to understand the message conveyed.

2. Overcoming the limitations of time space and sensory power.

3. Attract students' attention in the learning process.

4. Generating passion for student learning.

5. Allows for a more direct interaction between students with the environment and reality.

6. Allows students to learn on their own according to their abilities and interests.

7. Equalizing experiences and perceptions among students in receiving messages. ${ }^{17}$

\footnotetext{
${ }^{17}$ Syafruddin Nurdin, Kurikulum dan Pembelajaran (Jakarta: Rajawali Pers, 2016), h. 26.
} 
The position of the media in learning is very important. Because the media can support the success of learning. Even if examined further, the media is not only a channel for messages that must be fully controlled by sources in the form of people, but can also replace part of the duties of educators as presenters of teaching material. More clearly, the position of the media in learning can be described in the following $\operatorname{chart}^{18}$ :

Chart 1: The Position of the Media in Learning

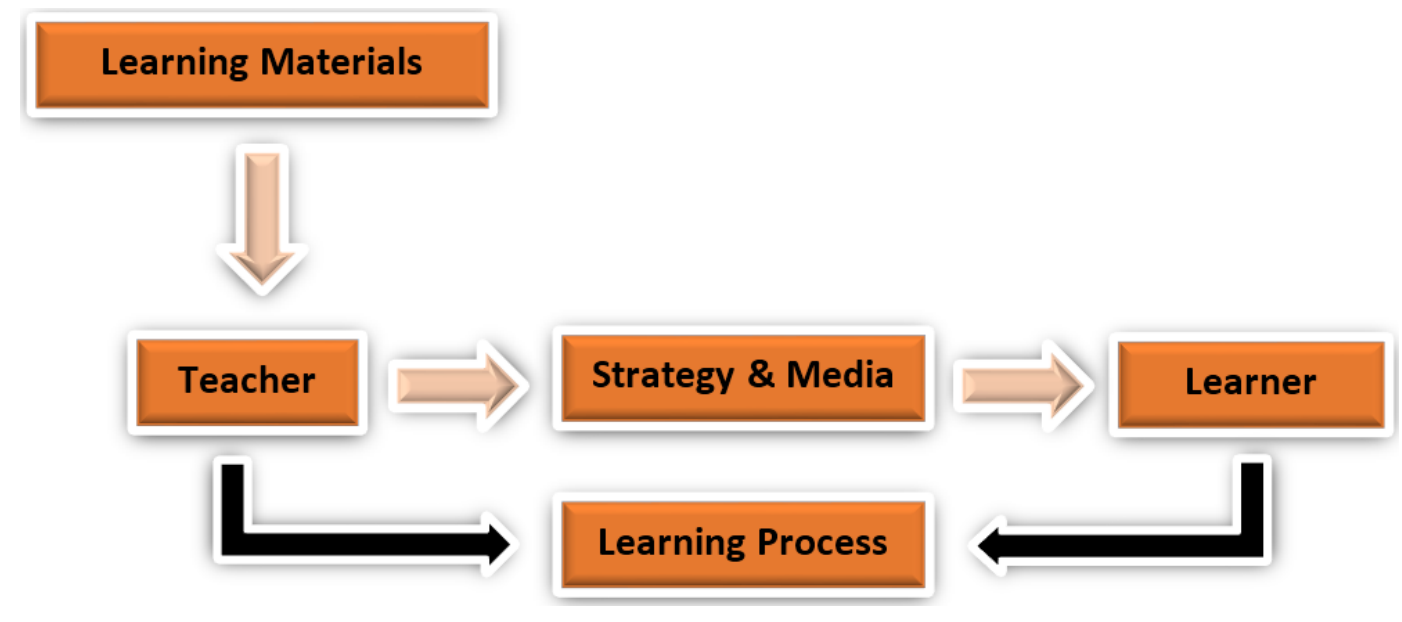

The chart and the statement above previously interpreted that learning requires media. The use of instructional media has long been considered an urgency in implementing the learning process. Thus internet-based Arabic learning media has several urgencies in online learning in the era of the global pandemic, including:

1. As a medium of connection to communicate, interact and meet face to face over long distances with students amidst the spread of Covid-19.

2. Can monitor the progress of students without having to look directly at the house.

3. Can communicate with student guardians to understand the character, complaints, and student shortcomings in learning.

4. Learning time can be conditional.

5. The relationship between teachers and students will be closer, because outside of learning from time to time the teacher can monitor students easily and can send motivation through text messages or voice.

6. Teachers and students do not need to follow health protocols (avoiding crowds, masks, washing hands, social distancing).

\footnotetext{
${ }^{18}$ Amka, Media Pembelajaran ..., h. 19-20.
} 


\section{Loghat Arabi: Jurnal Bahasa Arab \& Pendidikan Bahasa Arab}

\section{Conclusion}

Internet-based media is a means and equipment that requires an internet network for teaching and learning activities, and serves as a teacher's assistant to deliver learning material remotely according to the curriculum formulation to be achieved.

Internet-based Arabic learning media has several urgencies in online learning in the era of the global pandemic, including: (1) As a medium of connection to communicate, interact and meet face to face over long distances with students amidst the spread of Covid19, (2) Can monitor The development of students without having to look directly at their house, (3) Be able to communicate with the guardians of students to understand the character, complaints, and student shortcomings in learning, (4) Learning time can be conditional, (5) The relationship between teachers and students will be closer, because outside of learning at any time the teacher can monitor students easily and can send motivation via tech messages or voice, (6) Teachers and students do not need to follow health protocols.

\section{References}

Amka, Media Pembelajaran Inklusi, Sidoarjo: Nizamia Learning Center, 2016.

Arsyad, Azhar, Media Pengajaran, Jakarta: Raja Grafindo Persada, 2000.

Azzuhri, Muhandis, Metode dan Media Pembelajaran Bahasa Arab Berbasis Internet di Era Teknologi Informasi, dalam Insania: Jurnal Pemikiran Alternatif Kependidikan, Vol. 14, No. 3, 2009.

Handarini, Oktafia Ika, dan Siti Sri Wulandari, Pembelajaran Daring Sebagai Upaya Study From Home (SFH) Selama Pandemi Covid 19, dalam Jurnal Pendidikan Administrasi Perkantoran (JPAP), Vol. 8, No. 3, 2020.

Kementerian Pendidikan dan Kebudayaan, SE Mendikbud: Pembelajaran secara Daring dan Bekerja dari Rumah untuk Mencegah Penyebaran Covid-19, https://www.kemdikbud.go.id/main/blog/2020/03/se-mendikbud-pembelajaran-secaradaring-dan-bekerja-dari-rumah-untuk-mencegah-penyebaran-covid19 diakses pada tanggal 17 Nopember 2020.

Nurdin, Syafruddin, Kurikulum dan Pembelajaran, Jakarta: Rajawali Pers, 2016.

Pranita, Ellyvon, Diumumumkan Awal Maret, Ahli: Virus Corana Masuk Indonesia dari Januari, dalam situs berita https://www.kompas.com/sains/read/2020/05/11/130600623/diumumumkan-awal- 
maret-ahli--virus-corana-masuk-indonesia-dari-januari diakses pada tanggal 11 Nopember 2020.

Rusman, Perkembangan Teknologi Informasi, Jakarta: Raja Grafindo Perseda, 2007.

Sofyana dan Abdul, Pembelajaran Daring Kombinasi Berbasis Whatsapp Pada Kelas Karyawan Prodi Teknik Informatika Universitas PGRI Madiun, dalam Jurnal Nasional Pendidikan Teknik Informatika, Vol. 8, No. 1, 2019.

Susanto, Heri dan Helmi Akmal, Media Pembelajaran Sejarah Era Teknologi Informasi (Konsep Dasar, Prinsip Aplikatif, dan Perancangannya), Banjarmasin: Program Studi Pendidikan Sejarah Fakultas Keguruan dan Ilmu Pendidikan Universitas Lambung Mangkurat, 2019.

Taufik, Pembelajaran Bahasa Arab MI, Surabaya: UIN Sunan Ampel Press, 2016.

Uno, Hamzah B. dan Nina Lamatenggo, Teknologi Komunikasi dan Informasi Pembelajaran, Jakarta: Bumi Aksara, 2011.

Uno, Hamzah B. Model Pembelajaran: Menciptakan Proses Belajar Mengajar yang Kreatif dan Efektif, Jakarta: Bumi Aksara, 2010.

Warsita, Bambang, Teknologi Pembelajaran Landasan \& Aplikasinya, Jakarta: Rineka Cipta, 2008. 